\title{
Produksi dan Karakterisasi Gelatin dari Limbah Tulang Ayam dengan Menggunakan Spektrofotometer Ftir (Fourier Transform Infra Red)
}

\author{
Production and Characterization of Gelatin from Chicken Bone Waste using \\ Spectrofotometer Ftir (Fourier Transform Infra Red)
}

\author{
St. Maryam*, Nurmaya Effendi, Kasmah \\ Fakultas Farmasi Universitas Muslim Indonesia, Makassar \\ Corresponding author: St. Maryam: st.maryam@umi.ac.id \\ Submitted: 11-07-2019 Revised: 11-07-2019
}

Accepted: 11-07-2019

\begin{abstract}
ABSTRAK
Gelatin merupakan protein hasil hidrolisis parsial kolagen tulang dan kulit. Gelatin memiliki sifat yang khas, yaitu dapat berubah secara reversible dari bentuk sol ke bantuk gel, mengembang dalam air dingin, dapat membentuk film serta mempengaruhi viskositas suatu bahan, dan melindungi sistem koloid. Penelitian ini bertujuan untuk mengetahui persen rendamen serta menentukan karakteristik proksimat dan fisikokimia dari gelatin tulang ayam. Penelitian ini dilakukan dengan metode eksperimental, proses yang dilakukan untuk menghasilkan gelatin melalui beberapa tahap yaitu degreasing, demineralisasi, ekstraksi dan pengeringan. Kemudian gelatin hasil ekstraksi dari keempat perlakuan tersebut dilakukan beberapa pengujian seperti karakteristik proksimat (kadar air, abu, dan protein), dan karakteristik fisikokimia ( $\mathrm{pH}$ dan viskositas) serta identifikasi gugus fungsi menggunakan spektrofotometri Fourier Transform Infra Red (FTIR). Hasil penelitian ini menunjukkan persen rendamen gelatin 1,030\%, hasil karakterisasi proksimat yaitu kadar air 9,214\%, kadar abu 10,396\%, kadar protein 67,756\% dan hasil karakteristik fisikokimia yaitu pH 6, viskositas relatif $6 \mathrm{cP}$. Berdasarkan spektra FTIR, gugus fungsi gelatin tulang ayam yang dapat diidentifikasi diantaranya adalah gugus $\mathrm{O}-\mathrm{H}, \mathrm{N}-\mathrm{H}, \mathrm{C}-\mathrm{N}, \mathrm{C}=\mathrm{O} \& \mathrm{C}-\mathrm{H}$. Dari hasil penelitian yang didapatkan dapat disimpulkan bahwa gelatin dari tulang ayam memenuhi standar mutu gelatin.
\end{abstract}

Kata kunci: Gelatin, Tulang Ayam, Fourier Transform Infra Red (FTIR)

\begin{abstract}
Gelatin is a protein that is the result of partial hydrolisis of bone and skin collagen. Gelatin has a particular characteristic reversible change from the sol tl the gel, expanding in cold water, forming a film and affecting the viscosity of a material, and protecting the colloidal system. This study aimed to determine the percent of yield value and determine the proximate and physicochemical characteristics of chicken bone gelatin. This research was conducted by the experimental methode/ the process done to produce gelatin got through several stages, namely degreasing, demineralization, extraction, and drying. Then the gelatin extracted from the four treatments is carried out several tests such as proximate characteristics (moisture contevt, ash, and protein), and physicochemical characteristics ( $\mathrm{pH}$ and viscosity) and identification of functional groups used Fourier Transform Infra-Red (FTIR) spectrophotometry. The results showed that the percent of gelatin yield value is $1.030 \%$; the effects of proximate characterization are water content of $9.214 \%$, the ash content of $10.396 \%$, the protein level of $67.756 \%$ and physicochemical characteristic $p H$ 6, relative viscosity six Cp. Based on the FTIR spectra, the identifiable functional groups of chicken bone gelatin include the)-H, $\mathrm{N}-\mathrm{H}, \mathrm{C}-\mathrm{N}, \mathrm{C}=\mathrm{O}$ \& $\mathrm{C}-\mathrm{H}$. From the result of the research, it can be concluded that the gelatin from the chicken bone fulfils gelatin quality standard.
\end{abstract}

Keywords: Gelatin, Chicken Bone, Fourier Transform Infra Red (FTIR)

\section{PENDAHULUAN}

Di Indonesia saat ini banyak beredar bahan makanan, minuman ataupun obat-obatan berupa kapsul dan tablet yang menggunakan gelatin. Menurut Widyaninggar et al (2012) gelatin merupakan produk turunan protein yang diperoleh dari jaringan kolagen pada tulang dan kulit hewan. Beberapa contoh 
peranan penting gelatin di dalam industri makanan antara lain peranannya pada jenis produk permen, jenis produk bakery, dan jenis produk daging olahan (Kirk \& Othmer, 1966).

Dalam industri pangan, menurut Poppe (1992) gelatin digunakan sebagai pembentuk busa (whipping agent), pengikat (binder agent), penstabil (stabilizer), pembentuk gel (gelling agent), perekat (adhesive), peningkat viskositas (viscosity agent), pengemulsi (emulsifier), finning agent, crystal modifier, dan pengental (thickener). Menurut Septimus (1961), tulang ayam tersusun oleh komponen utama kalsium fosfat $(57,35 \%)$, kolagen $(33,3 \%)$, dan kalsium karbonat $(3,85 \%)$.

Gelita Group (2008) melaporkan bahwa bahan baku yang digunakan oleh para produsen gelatin dunia mayoritas adalah kulit babi (46\%), disusul oleh kulit sapi (28\%), tulang sapi (24\%), dan bahan lainnya (2\%). Status haram pada produk-produk berbahan dasar babi dan kasus zoonosis sapi gila di negara-negara produsen gelatin (Eropa dan Amerika) sama sekali tidak menurunkan permintaan pasar Indonesia terhadap gelatin impor. Hal ini terbukti dengan terus meningkatnya nilai impor gelatin Indonesia. Tingginya kebutuhan akan gelatin yang halal dan sehat di Indonesia dapat dipenuhi bila tulang ayam dapat dimanfaatkan sebagai bahan baku menurut Septimus (1961).

Menurut penelitian yang telah dilakukan oleh Nurul dkk (2013) Pada pembuatan gelatin tulang kaki ayam menggunakan perlakuan asam, dimana pelarut yang digunakan adalah $\mathrm{HCl}$. Pelarut tersebut digunakan untuk merendam tulang kaki ayam, dimana pelarut asam akan menghidrolisis kolagen menjadi gelatin. Selain itu proses hidrolisis kolagen menjadi gelatin pada proses perendaman membutuhkan waktu yang relatif lama. Kombinasi perlakuan yang paling baik adalah lama perendaman 24 jam dan konsentrasi $4 \%$ berdasarkan parameter viskositas sebesar 5,95 cP, kekuatan gel sebesar 139,38 bloom, kadar abu sebesar 2,93 \%, kadar air sebesar 7,3 \%, pH sebesar 5,77.

Seperti yang di ketahui bahwa pemanfaatan gelatin dalam industri pangan dan non pangan sangat besar dan semakin meluas, namun yang menjadi permasalahan adalah bahan baku yang digunakan sebagai sumber gelatin saat ini sebagian besar berasal dari babi, yang dilarang di konsumsi oleh umat Islam. Banyaknya kebutuhan gelatin di Indonesia menuntut ketersediaan gelatin dalam jumlah besar, sehingga pengolahan gelatin dari tulang ayam menjadi salah satu alternatif dalam memenuhi kebutuhan produk halal di Indonesia.

Berangkat dari masalah tersebut, maka akan dilakukan penelitian Produksi dan Karakterisasi Gelatin Tulang Ayam dengan Menggunakan Spektrofotometer FTIR.

\section{Tujuan Penelitian}

Untuk memperoleh dan mengkarakterisasi gelatin dari tulang ayam dengan menggunakan spektrofotometer fourier transform infra red (FTIR).

\section{METODOLOGI \\ Alat Dan Bahan}

Alat yang digunakan pada penelitian ini adalah alat destilasi, alat penggiling, beaker glass, buret, cawan porselen, corong, erlenmeyer, gegep, gelas kimia, gelas ukur, hair dryer, labu Kjeldahl, magnetic stirrer, oven, penangas air, pH meter, pipet volume, pisau, spektrofotometer FTIR, tanur, termometer, timbangan analitik, viskometer Brookfield.

Bahan yang digunakan pada penelitian ini adalah aluminium foil, aquadest, $\mathrm{CuSO}_{4}, \mathrm{HCl} 0,01$ $\mathrm{N}, \mathrm{HCl} 5 \%, \mathrm{H}_{2} \mathrm{SO}_{4}$ pekat, $\mathrm{H} 3 \mathrm{BO} 32 \%$, indikator metil merah, indikator metil biru, kertas saring, $\mathrm{K}_{2} \mathrm{SO}_{4}, \mathrm{NaOH} 50 \%, \mathrm{Na}_{2} \mathrm{SO}_{4}$, tulang ayam.

\section{Tahapan Penelitian}

\section{Degreasing (Junianto, 2006)}

Bahan baku yang digunakan adalah tulang ayam. Tulang-tulang tersebut dibersihkan dari sisa-sisa daging dan lemak yang masih menempel (degreasing) yaitu dengan direndam dalam air mendidih selama 30 menit sambil diaduk-aduk. Selanjutnya tulang ditiriskan dan dipotong kecil-kecil $(3-5 \mathrm{~cm})$ untuk memperluas permukaan.

\section{Demineralisasi (Junianto, 2006)}

Bahan baku yang telah bersih itu kemudian direndam dengan larutan $\mathrm{HCl}$ 5\% dalam wadah selama 48 jam sampai terbentuk ossein, ossein adalah tulang yang lunak. Ossein dicuci dengan menggunakan aquadest sampai pHnya netral (6-7).

\section{Ekstraksi (Junianto, 2006)}

Ossein yang ber-pH netral tersebut dimasukkan ke dalam beaker glass dan 
ditambahkan aquadest, perbandingan ossein dengan aquadest adalah 1:3 (b/v). Setelah itu diekstraksi dalam waterbath pada suhu $90^{\circ} \mathrm{C}$ selama 7 jam. Kemudian disaring dengan kertas saring. Hasil saringan kemudian dipekatkan.

\section{Pengeringan (Junianto, 2006)}

Cairan pekat gelatin yang diperoleh kemudian dituang ke dalam wadah untuk dikeringkan dalam oven pada suhu $50^{\circ} \mathrm{C}$ selama 24 jam, setelah kering kemudian digiling dan dianalis.

\section{Pengamatan}

Pengamatan dilakukan terhadap rendemen, karakteristik proksimat dan karakteristik fisikokimia gelatin, serta karakteristik gugus fungsi menggunakan spektrofotometer FTIR. Karakteristik proksimat meliputi kadar air, kadar abu, dan kadar protein. Karakteristik fisikokimia meliputi $\mathrm{pH}$, dan viskositas.

\section{Rendemen (Junianto, 2006)}

Rendemen diperoleh dari perbandingan berat kering gelatin yang dihasilkan dengan berat bahan segar (tulang yang telah dicuci bersih). Besarnya rendemen dapat diperoleh dengan menggunakan rumus:

Rendamen $=\frac{\text { Berat gelatin yang diperoleh }}{\text { Berat Bahan Segar }} \times 100 \%$

\section{Karakteristik Proksimat (Junianto, 2006) Kadar Air}

Cawan porselen dikeringkan pada suhu $105^{\circ} \mathrm{C}$ selama 1 jam. Kemudian didinginkan dan ditimbang. Sampel yang akan ditentukan kadar airnya ditimbang sebanyak 0,5 gram. Cawan yang telah berisi sampel dimasukkan ke dalam oven bersuhu $105^{\circ} \mathrm{C}$ selama 24 jam, lalu didingainkan dalam desikator dan ditimbang hingga diperoleh berat konstan. Kadar air dihitung dengan rumus:

$$
\text { Kadar air }(\%)=\frac{(\mathrm{Wa}-\mathrm{Wb})}{\mathrm{W}} \times 100 \%
$$

Keterangan: $\mathrm{Wa}=$ berat cawan + sampel awal (gram); $\mathrm{Wb}=$ berat cawan + Sampel akhir (gram); W = Bobot sampel (gram).

\section{Kadar Abu}

Sampel yang diuapkan airnya dimasukkan ke dalam tanur bersuhu $600^{\circ} \mathrm{C}$, sebelumnya berat cawan kering dan berat contoh telah diketahui. Proses penguapan dilakukan selama 6 jam sampai semua bahan berubah warna menjadi abu-abu, kemudian sampel didinginkan lalu ditimbang. Kadar abu dihitung dengan rumus:

$$
\text { Kadar Abu (\%)= } \frac{\mathrm{W} 2-\mathrm{W} 1}{\mathrm{~W}} \times 100 \%
$$

Keterangan: $\mathrm{W} 1$ = berat cawan kosong (gram); $\mathrm{Wb}=$ berat cawan + Sampel akhir (gram); $\mathrm{W}=$ Bobot sampel (gram)

\section{Kadar Protein Metode Mikro Kjeldahl}

Sejumlah 0.02-0.05 gram dimasukkan dalam labu Kjeldahl $100 \mathrm{~mL}$ kemudian ditambah 2- 3 gram katalis (1,2 gram $\mathrm{Na}_{2} \mathrm{SO}_{4}$ dan 1 gram $\mathrm{CuSO}_{4}$ ) dan 2- $3 \mathrm{~mL} \mathrm{H}_{2} \mathrm{SO}_{4}$ pekat, lalu dilakukan destruksi hingga larutan menjadi jernih. Setelah itu didinginkan kemudian sampel didestilasi dan ditambah $35 \mathrm{~mL}$ aquades dan $10 \mathrm{~mL} \mathrm{NaOH}$ 50\%. Hasil destilasi ditampung dalam erlenmeyer berisi $5 \mathrm{~mL} \mathrm{H}_{3} \mathrm{BO}_{3} 2 \%$ dan indikator metil merah dan metil biru kemudian dititrasi dengan $\mathrm{HCl} 0.01 \mathrm{~N}$. Kadar protein dihitung dengan rumus:

$$
\% \mathrm{~N}=\frac{(\mathrm{Va}-\mathrm{Vb}) \mathrm{HCl} \times \mathrm{N} \mathrm{HCl} \times 14,007}{\mathrm{~W}} \times 100 \%
$$

Keterangan: $\mathrm{Va}=\mathrm{mL} \mathrm{HCl}$ untuk titrasi contoh; $\mathrm{Vb}=$ mLHCl untuk titrasi blangko; $\mathrm{N}=$ Normalitas $\mathrm{HCl}$ standar yang digunakan.; 14,007 = Berat atom nitrogen; 6,25 $=$ Faktor konversi protein untuk ikan; $\mathrm{W}=$ Berat contoh $(\mathrm{mg})$

\section{Karakteristik Fisikokimia pH (Junianto, 2006)}

Sampel sebanyak 0,2 gram ditimbang dan dilarutkan ke dalam $20 \mathrm{ml}$ air pada suhu $25^{\circ} \mathrm{C}$. Sampel dihomogenkan dengan magnetic stirrer, kemudian diukur derajat keasamannya pada suhu kamar dengan $\mathrm{pH}$ meter.

Viskositas (Goycoolea \& Adriana, 2003)

Larutan gelatin $1 \%$ dilarutkan dengan menggunakan aquadest pada suhu $88^{\circ} \mathrm{C}$ dan diukur menggunakan viskometer. 
Nilai viskositas dalam satuan centipoises (cP). Spindel yang digunakan adalah spindle 3 dengan kecepatan 50 rpm pada suhu ruang.

\section{Karakterisasi Gugus Fungsi Gelatin (Puspawati, 2012) \\ Gugus fungsi gelatin dikarakterisasi} dengan spektrofotometer Fourier Transform Infra Red (FTIR) dengan metode pelet $\mathrm{KBr}$. Sampel bubuk gelatin sebanyak $2 \mathrm{mg}$ dicampur dengan $100 \mathrm{mg}$ serbuk kering $\mathrm{KBr}$ dan ditumbuk hingga halus. Campuran tersebut kemudian dimaampatkan dalam sebuah cetakan menggunakan pompa hidrolik sehingga membentuk kepingan tipis (pelet). Karakterisasi terhadap kepingan sampel dilakuan dengan spektrometer FTIR pada panjang gelombang $4000-500 \mathrm{~cm}^{-1}$.

\section{Analisis Data}

Data yang diperoleh dengan melakukan analisis kuantitatif dan kualitatif. Analisa kuantitatif berdasarkan karakterisasi gelatin hasil ekstraksi berdasarkan standar yang telah ditetapkan. Analisa kualitatif dengan menggunakan metode spektrofotometer FTIR dan dilakukan perbandingan kemiripan spektrum berdasarkan parameter harga match factor (MF).

\section{HASIL DAN PEMBAHASAN}

Penelitian ini dimulai dengan melakukan proses degreasing yang bertujuan untuk membersihkan tulang ayam dari sisa-sisa daging dan lemak yang menempel pada tulang. Proses ini dilakukan dengan cara merendam tulang ayam pada air mendidih selama \pm 30 menit dengan suhu tidak lebih dari $80^{\circ} \mathrm{C}$ sambil diaduk dengan tujuan untuk melarutkan lemak sehingga tulang ayam terbebas dari kotoran agar hasil dapat diperoleh secara optimum.

Pengecilan atau pemotongan ukuran tulang ayam sekitar 3-5 cm dilakukan sebelum masuk pada proses selanjutnya yaitu proses demineralisasi dan ekstraksi. Pengecilan ukuran tulang bertujuan untuk memperluas bidang permukaan dan memudahkan proses demineralisasi sehingga reaksi berlangsung lebih cepat.

Untuk memperoleh gelatin dari tulang ayam, tahap yang terpenting yaitu demineralisasi dan ekstraksi. Proses demineralisasi dilakukan dengan cara merendam tulang dalam asam kuat, asam yang digunakan yaitu asam klorida ( $\mathrm{HCl}$ ) 5\% selama 3 hari, pada tahap ini senyawa asam dapat mengubah serat kolagen triple-heliks menjadi rantai tunggal. Kalsium merupakan mineral yang ada dalam tulang, maka dari itu tujuan dari perendaman tulang-tulang dengan larutan asam ini adalah untuk menghilangkan garam kalsium lain yang terdapat pada tulang ayam.

Hasil akhir reaksi ketiganya menghasilkan garam kalsium terlarut. Akibat adanya materi terlarut tersebut, tulang ayam menjadi lunak atau biasa disebut ossein. Larutan asam juga menjadi keruh.

Setelah itu ossein dinetralkan menggunakan aquadest atau air mengalir hingga $\mathrm{pH}$ netral, demineralisasi dilanjutkan dengan ekstraksi menggunakan aquadest pada suhu $70^{\circ} \mathrm{C}$ selama 5 jam. Suhu ini berada di atas suhu susut kolagen, yaitu diatas $60^{\circ} \mathrm{C}-70^{\circ} \mathrm{C}$. Jika suhu ekstraksi lebih tinggi maka akan terjadi kerusakan protein. Pemanasan akan memecahkan struktur heliks dan ikatan peptida kolagen menjadi rantai terpisah, yang dinamakan gelatin. Hasil ekstraksi yang didapatkan berupa larutan berwarna kuning, dan tulang yang begitu lunak, Kolagen yang telah berubah menjadi gelatin dapat dilihat dari tulang yang mulai mengapung dan lengket. Hasil ekstrak kemudian dipekatkan dan dikeringkan dalam oven pada suhu $50^{\circ} \mathrm{C}$ hingga sampel menjadi kering lalu diolah hingga menjadi serbuk gelatin.

Hasil ekstrak yang didapatkan dilakukan pengamatan yang terdiri dari \% rendamen, karakteristik proksimat (kadar air, kadar abu, kadar protein), karakteristik fisikokimia $(\mathrm{pH}$, viskositas) dan penentuan gugus fungsi menggunakan spektrofotometer Fourier Transform Infra Red (FTIR).

Rendamen merupakan salah satu parameter yang penting dalam pembuatan gelatin. Semakin banyak rendamen yang dihasilkan maka semakin efesien perlakuan yang diberikan. Berdasarkan hasil penelitian rendamen yang dihasilkan menggunakan sampel tulang ayam yaitu sebanyak 1,030\%.

Menurut (Muliyani, dkk 2012 dalam Siregar, dkk 2015) penggunaan asam yang terlalu kuat menjadikan kolagen yang tersusun oleh peptida-peptida asam amino yang merupakan struktur utama pembentuk kolagen terdenaturasi lebih lanjut. Terdenaturasinya penyusun kolagen menyebabkan bahan penyusun ikut terbuang pada proses pencucian 
Tabel I. Karakteristik proksimat gelatin tulang ayam

\begin{tabular}{lcc}
\hline Karakteristik & \multicolumn{2}{c}{ Jumlah (\%) } \\
\cline { 2 - 3 } Proksimat & Tulang ayam & SNI No. 06-3735a (Standar Mutu Gelatin) \\
\hline Kadar air & $9,214 \%$ & Maks $16 \%$ \\
Kadar abu & $2,200 \%$ & Maks $3,25 \%$ \\
Kadar Protein & $67,758 \%$ & $87,25 \%$ \\
\hline
\end{tabular}

ossein sehingga rendamen yang dihasilkan menurun. Hal inilah yang menyebabkan rendemen pada perendaman dengan asam klorida lebih rendah. Konsentrasi asam yang berlebih dan suhu yang tinggi menimbulkan adanya hidrolisis lanjutan sehingga sebagian gelatin turut terdegradasi dan menyebabkan turunnya jumlah gelatin. Konversi kolagen menjadi gelatin dipengaruhi oleh suhu, waktu pemanasan dan $\mathrm{pH}$.

\section{Karakteristik Proksimat}

Adapun hasil karakteristik proksimat dari gelatin tulang ayam (Tabel I).

\section{Kadar Air}

Pengujian kadar air bertujuan untuk mengetahui kandungan air dalam gelatin. Kadar air gelatin sangat berpengaruh terhadap umur simpan, karena erat kaitannya dengan aktiitas mikroorganisme yang terjadi selama gelatin tersebut disimpan serta dapat mempengaruhi penampakan, tekstur serta cita rasa bahan makanan hasil olahan menggunakan gelatin tersebut (Jannah A, dkk 2013).

Hasil pengukuran kadar air dari gelatin tulang ayam dengan beberapa replikasi (Tabel V) yaitu 9,214\%, dimana hasil tersebut masih memenuhi standar mutu gelatin yaitu maksimal 16\% menurut Standar Nasional Indonesia 1995.

\section{Kadar Abu}

Tujuan dari analisa kadar abu adalah untuk mengetahui secara umum kandungan mineral yang terdapat dalam bahan dan merupakan salah satu parameter untuk menilai kualitas gelatin terutama dalam hal kemurnian gelatin. Kadar abu yang didapatkan dari sampel tulang ayam (Tabel V) yaitu sebesar 2,200\%, dimana kadar abu gelatin ini dinilai telah memenuhi Standar Nasional Indonesia 1995 yaitu maksimum 3,25\%.

Menurut (Jannah A, dkk 2013) adapun hasil dari nilai kadar abu yang tinggi disebabkan pada sampel yang mempunyai tulang yang sangat rapuh dan mudah sekali hancur pada saat perendaman yaitu dalam bentuk ossein. Ossein dalam bentuk serbuk mudah sekali lolos dalam penyaringan dalam kertas saring biasa sehingga pada saat ekstraksi gelatin serbuk ossein akan bergabung menjadi gelatin.

\section{Kadar Protein}

Protein merupakan kandungan yang tertinggi di dalam gelatin. Gelatin sebagai salah satu jenis protein konversi yang dihasilkan melalui proses hidrolisis kolagen, pada dasarnya memiliki kadar protein yang tinggi (Suptijah, 2013). Gelatin sebagai salah satu jenis protein konversi yang dihasilkan melalui proses hidrolisis kolagen, tentu memiliki kadar protein yang tinggi. Gelatin merupakan suatu protein murni yang diperoleh dari penguraian kolagen dengan panas (Wiratmaja, 2006).

Berdasarkan hasil penelitian kadar protein tulang ayam yang diperoleh (Tabel V) yaitu $67,758 \%$. Kadar protein gelatin meningkat seiring penambahan waktu perendaman, namun pada perendaman selama beberapa hari menyebabkan kadar protein menurun. Menurut Siregar, H (2015) hal ini dikarenakan dengan semakin lamanya waktu perendaman maka kolagen yang terbentuk akan terlarut dalam larutan asam, akibatnya kolagen yang dapat dikonversikan menjadi gelatin berkurang dan juga kuatnya asam dapat merusak struktur dari protein kolagen, sehingga kadar protein akan menurun.

Bila dibandingkan dengan kadar protein menurut (SNI) yaitu sekitar 87,25\%, rendahnya kadar protein yang diperoleh dikarenakan sumber bahan baku yang kurang segar karena sampel yang digunakan berasal dari limbah.

\section{Karakteristik Fisikokimia}

Hasil karakteristik fisikokimia dari tulang ayam (Tabel II). 
Tabel II. Karakteristik fisikokimia gelatin tulang ayam

\begin{tabular}{lcc}
\hline Karakteristik fisikokimia & Tulang ayam & $\begin{array}{c}\text { British Standard 757 (Standar Mutu } \\
\text { Gelatin) }\end{array}$ \\
\hline $\mathrm{pH}$ & 6,0 & $4,5-6,5$ \\
Viskositas & $6 \mathrm{Cp}$ & $1,5-7 \mathrm{cP}$ \\
\hline
\end{tabular}

\section{Derajat Keasaman (pH)}

Hasil pengukuran $\mathrm{pH}$ gelatin tulang ayam dalam penelitian ini yaitu didapatkan $\mathrm{pH}$ dengan nilai 6. Hasil yang didapatkan tersebut masih memenuhi British standar 757 (1995) dari gelatin yang berkisar antara $\mathrm{pH}$ 4,5-6,5

Derajat keasaman $(\mathrm{pH})$ gelatin diperoleh dengan cara pengukuran produk gelatin yang dilarutkan dalam aquades. Nilai $\mathrm{pH}$ gelatin berhubungan dengan proses yang dilakukan (Kusumawati 2008). Struktur ikatan asam amino pada molekul kolagen mengalami pembukaan dan bahan curing akan terperangkap didalam ikatan tersebut dan tidak larut saat proses netralisasi yang secara langsung akan mempengaruhi nilai $\mathrm{pH}$ akhir gelatin yang dihasilkan (Amertaningtyas D, dkk 2015)

\section{Viskositas}

Viskositas merupakan salah satu sifat fisik gelatin yang cukup penting. viskositas merupakan daya aliran molekul dalam suatu larutan. Pengujian viskositas dilakukan untuk mengetahui tingkat kekentalan gelatin sebagai larutan (Leiner 2006 dalam Nurul Huda 2013)

Semakin tinggi nilai viskositas gelatin bahan baku, maka ketahanan dalam air akan semakin lama. Pada Tabel VI dapat dilihat bahwa nilai viskositas dari gelatin tulang ayam yang didapatkan yaitu $6 \mathrm{cP}$, nilai yang didapatkan tersebut masih memenuhi British Standard 757 untuk gelatin yaitu 1,5-7 cP.

Faktor yang mempengaruhi viskositas adalah pH. Konsentrasi $\mathrm{HCl}$ yang semakin tinggi, menyebabkan kation asam yang terperangkap dalam ossein semakin banyak, sehingga $\mathrm{pH}$ yang terukur semakin rendah (asam) dan hidrolisis kolagen akan berlanjut pada proses penguraian polimer kolagen. Penguraian polimer dapat berakibat diperolehnya berat molekul (BM) polydispersity yang lebih rendah atau terbentuk polimer turunan yang mengakibatkan rendahnya viskositas (Rinta, 2008).

Selain $\mathrm{pH}$, viskositas gelatin dipengaruhi oleh temperatur, konsentrasi, dan teknik perlakuan seperti penambahan elektrolit lain dalam larutan gelatin. Makin tinggi konsentrasi gelatin maka viskositasnya akan semakin tinggi dan semakin panjang rantai asam amino gelatine maka nilai viskositas semakin besar. Panjang rantai asam amino dalam gelatin ditentukan oleh suhu yang digunakan saat proses ekstraksi. Penggunaan suhu yang terlalu tinggi dapat mengakibatkan terjadi hidrolisis lanjutan pada kolagen yang sudah menjadi gelatin sehingga akan memutuskan rangkaian asam amino sehingga viskositasnya rendah (Junianto, 2006).

\section{Spektrofotometer FTIR}

Analisis FTIR dilakukan untuk memastikan senyawa yang dihasilkan adalah gelatin dengan membandingkan hasil spektrum sampel dan dengan standar gelatin. Menurut Che-Man YB (2010) Analisis FTIR merupakan teknik analisis yang cepat dan nondestruktif, sensitif dan memerlukan preparasi sampel yang sederhana, serta penggunaan reagen kimia dan pelarut dalam jumlah sedikit.

Struktur gelatin seperti umumnya protein memiliki gugus karbonil, amina, dan hidroksil (Martianingsih dan Atmaja 2010). Menurut Puspawati et al. (2012), gelatin memunculkan serapan IR khas amida A pada bilangan gelombang $3600-2300 \mathrm{~cm}^{-1}$, amida I pada $1636-1661 \mathrm{~cm}^{-1}$, amida II pada $1560-1335$ $\mathrm{cm}^{-1}$, dan amida III pada $1300-1200 \mathrm{~cm}^{-1}$.

Menurut Sankari (2010) dalam Sjahfird L et al., 2015 Prinsip kerja FTIR adalah mengenali gugus fungsi suatu senyawa dari absorbansi inframerah yang dilakukan terhadap senyawa tersebut. Pola absorbansi yang diserap oleh tiap-tiap senyawa berbeda-beda, sehingga senyawa-senyawa dapat dibedakan dan dikuantifikasikan (Sankari, 2010). 


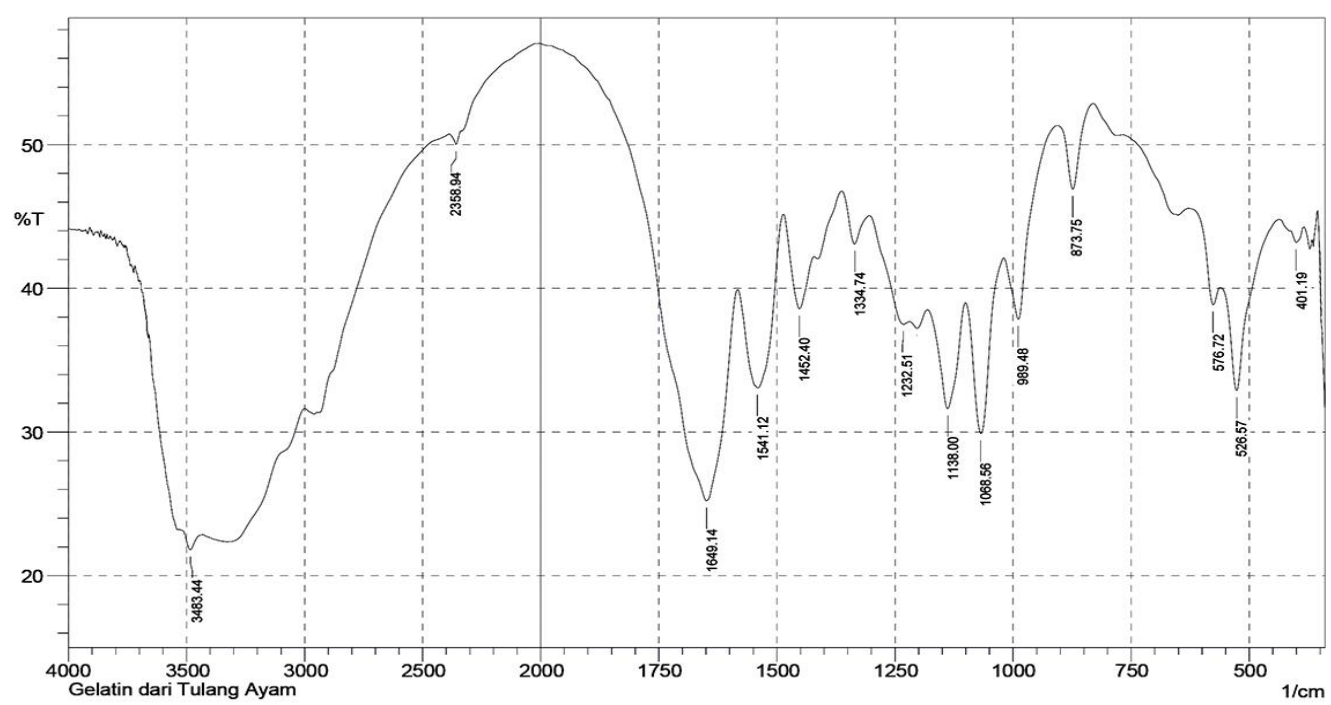

Gambar 1. Spektrum hasil pengukuran gelatin dari tulang ayam dengan menggunakan spektrofotometer FTIR

Tabel III. Karakteristik gugus fungsi gelatin tulang ayam

\begin{tabular}{|c|c|c|c|c|c|}
\hline $\begin{array}{l}\text { Daerah } \\
\text { serapan }\end{array}$ & $\begin{array}{l}\text { Wilayah } \\
\text { serapan } \\
\text { gelatin } \\
\left(\mathrm{cm}^{-1}\right)\end{array}$ & $\begin{array}{c}\text { Bilangan } \\
\text { gelombang } \\
\text { gelatin tulang } \\
\text { ayam } \\
\left(\mathrm{cm}^{-1}\right) \\
\end{array}$ & $\begin{array}{l}\text { Bilangan } \\
\text { gelomban } \\
\text { g standar } \\
\left(\mathrm{cm}^{-1}\right)\end{array}$ & Keterangan & Referensi \\
\hline \multirow[t]{2}{*}{ Amida A } & $3600-2300$ & 3483,44 & 3454 & $\begin{array}{l}\text { OH streaching } \\
\text { NH stretching }\end{array}$ & $\begin{array}{l}\text { Muyonga et } \\
\text { al., (2004) }\end{array}$ \\
\hline & & 2358,94 & 2355 & $\begin{array}{l}\mathrm{CH}_{2} \text { stretching, } \\
\mathrm{NH} \text { stretchin, } \mathrm{OH}\end{array}$ & \\
\hline Amida I & 1661-1636 & 1649,14 & 1695 & $\mathrm{C}=0$ stretching & $\begin{array}{l}\text { Muyonga et } \\
\text { al., (2004) }\end{array}$ \\
\hline Amida II & $1560-1335$ & 1541,12 & 1522 & $\begin{array}{l}\text { NH bending, } \\
\text { CN stretching }\end{array}$ & $\begin{array}{l}\text { Muyonga et } \\
\text { al., (2004) }\end{array}$ \\
\hline Amida III & $1300-1200$ & 1232,51 & 1232 & $\begin{array}{l}\mathrm{NH} \text { bending, } \\
\mathrm{C}=\mathrm{O} \text { stretching, - } \\
\mathrm{CH}_{2}\end{array}$ & $\begin{array}{l}\text { Muyonga et } \\
\text { al., (2004) }\end{array}$ \\
\hline
\end{tabular}

Hasil spektra inframerah disajikan pada Gambar 3 sedangkan karakteristik gugus fungsi gelatin (Tabel VII).

Pada kura serapan amida A, sampel menunjukkan serapan melebar pada 3483,44 $\mathrm{cm}^{-1}$. Puncak serapan ini disebabkan oleh adanya ikatan regangan $\mathrm{N}-\mathrm{H}$ dari gugus amida yang berasosiasi dengan ikatan hidrogen, dan adanya gugus $\mathrm{OH}$. Bentuk puncak yang melebar merupakan bukti adanya gugus $\mathrm{OH}$ dari hidroksiprolin. Kebanyakan puncak NH bebas yang diserap mempunyai bentuk sempit dan tajam pada $3650-3580 \mathrm{~cm}^{-1}$. Apabila gugus $\mathrm{NH}$ dari suatu peptida terlibat dalam ikatan hidrogen, maka posisinya akan bergeser ke bilangan gelombang atau frekuensi yang lebih rendah dan terdapatnya kemungkinan pertindihan ikatan $\mathrm{NH}$ dengan gugus $\mathrm{OH}$ pada daerah tersebut, yang menyebabkan terjadinya serapan dengan puncak yang melebar. Bagian amida A yang kedua adalah serapan pada 2930-2300 $\mathrm{cm}^{-1}$. Sampel menunjukkan serapan pada 2358,94 $\mathrm{cm}^{-1}$, puncak ini menunjukkan bahwa gugus $\mathrm{NH}$ 
dalam amida akan cenderung berikatan dengan dengan regangan $\mathrm{CH}_{2}$ apabila gugus karboksilat dalam keadaan stabil. Dengan demikian sampel yang diuji telah terbukti memiliki gugus $\mathrm{OH}$, regangan $\mathrm{NH}$, dan regangan $\mathrm{CH}_{2}$.

Gugus khas gelatin berikutnya adalah amida I. Puncak serapan pada frekuensi 1661$1636 \mathrm{~cm}^{-1}$ yang disebut sebagai kura serapan amida I. Sampel menunjukkan serapan pada $1649,14 \mathrm{~cm}^{-1}$, serapan ini disebabkan oleh adanya regangan ikatan ganda gugus karbonil $\mathrm{C}=\mathrm{O}$, bending ikatan $\mathrm{NH}$, dan regangan $\mathrm{CN}$. Daerah serapan amida I ini menunjukkan adanya regangan $\mathrm{C}=0$.

Daerah serapan amida II adalah puncak serapan pada $1560-1335 \mathrm{~cm}^{-1}$. ibrasi amida II disebabkan oleh adanya deformasi ikatan NH dalam protein. Hasil pengukuran terhadap gelatin tulang ayam menunjukkan puncak serapan 1541,12 $\mathrm{cm}^{-1}$. Hal ini membuktikan adanya deformasi ikatan $\mathrm{N}-\mathrm{H}$ pada gelatin tulang ayam.

Daerah serapan spesifik dari gelatin yang terakhir adalah amida III.

Puncak serapannya adalah 1300-1200 $\mathrm{cm}^{-1}$ dan berhubungan dengan struktur triplehelix. Hasil pengukuran terhadap gelatin tulang ayam menunjukkan puncak serapan 1232,51 $\mathrm{cm}^{-1}$. Hal ini menunjukkan gelatin tulang ayam masih mengandung struktur triple heliks (kolagen). Hal ini berarti masih ada sebagian kecil struktur kolagen yang masih belum terkonversi menjadi gelatin dan lolos saat dilakukan penyaringan ekstrak gelatin.

Keseluruhan dari kurva spektra FTIR untuk gelatin hasil ekstraksi tulang ayam memiliki intensitas dari amida A sampai amida II yang semakin besar. Puncak-puncak pada amida III hampir tak terlihat, dan setalah dilakukan perbandingan antara hasil pengukuran FTIR pada gelatin standar dan gelatin tulang ayam dapat dilihat bahwa keduanya memiliki gugus fungsi yang identik. Hal ini sudah sesuai dengan teori bahwa kolagen telah berhasil didenaturasi menjadi gelatin.

\section{KESIMPULAN}

Berdasarkan hasil penelitian yang telah dilakukan, maka dapat disimpulkan bahwa karakteristik proksimat gelatin yang dihasilkan dari tulang ayam yaitu kadar air 9,214\%, kadar abu $2,200 \%$ dan kadar protein $67,758 \%$.
Sedangkan, karakteristik fisikokimianya yaitu pH 6 dan viskositas 6 cP. Hasil yang didapatkan hampir memenuhi standar mutu gelatin, tetapi untuk kadar protein yang didapatkan tidak memenuhi standar disebabkan proses isolasi gelatin atau sumber bahan baku yang kurang segar. Spektrum FTIR antara gelatin standar dan gelatin hasil ekstraksi menunjukkan kemiripan mengandung gugus $\mathrm{OH}, \mathrm{NH}, \mathrm{CH}_{2}, \mathrm{C}=\mathrm{O}, \mathrm{C}-\mathrm{H}$ dan C-N

\section{SARAN}

Perlunya melakukan penelitian lebih lanjut mengenai gelatin yang diproduksi dari tulang ayam seperti pengujian masa simpan gelatin, uji logam berat, uji mikrobiologi dan lain-lain untuk memenuhi standar nasional kebutuhan konsumsi gelatin atau dilakukan alidasi metode pengujian untuk gelatin. Selain itu, perlu pula dilakukan pengkajian lebih lanjut dalam penggunaan asam dan suhu ekstraksi agar memperoleh hasil yang lebih baik.

\section{DAFTAR PUSTAKA}

Amertaningtyas, D, Purnomo H, dan Siswanto, 2005, Kualitas Nuggets daging ayam boiler dan ayam petelur afkir dengan menggunakan tapioka dan tapioka modifikasi serta lama pengukusan yang berbeda, Progrma pascasarjan Universitas Brawijaya, Malang

British Standard 1975, Sampling and testing of gelatin, Academic Press, New York.

Che Man, Y. B, Syahariza, Z.A, dan A.Rohman 2010, Chapter 1. Fouriertransform infrared (FTIR) spectroscopy: development, techniques, andapplication in the analysis of fats and oils, in Fourier Transform InfraredSpectroscopy (ed Oliver J. Ress), Nova Science Publisher, NewYork, USA.

Goycoolea, FM, \& Cardenas, A 2003, Pectins from opuntia spp : A short reiew, JPACD.

Jannah, A, Maunatin, A, Windayanti, A, Findianti, Y, Mufidah, Z 2013, Isolasi dan Karakterisasi Gelatin Dari Tulang Ayam Dengan Metode Asam, UIN Maulana Malik Ibrahim, Malang.

Junianto, Haetami, K\& Maulina, I 2006, Produksi gelatin dari tulang ayamdan pemanfaatannya sebagai bahan dasar pembuatan cangkang kapsul, Uniersitas Padjajaran, Bandung. 
Kirk, RE \& Othmer, DF 1966, Encyclopedia of chemical technology, ol. X,The Interscience Encyclopedia Inc, New York. Kusumawati, Rinta, Tazwir, dan Wawasto, Ari 2008, Pengaruh Perendaman dalam Asam Klorida terhadap Kualitas Gelatin Tulang Kakap Merah, Jurnal Pascapanen dan Bioteknologi Kelautan dan Perikanan Vol. 3 No.1.

Martianingsih, Niniet dan Lukman Atmaja 2010, Analisis Sifat Kimia, Fisika dan Termal Gelatin dari Ekstraksi Kulit Ikan Pari (Himantura gerrardi) melalui Variasi Jenis Larutan Asam, Prosiding Kimia.

Nurul,W, Atmaka,W, Nurhartadi,E 2013, Kajian karakteristik fisik dan kimia gelatin ekstrak tulang kaki ayam (Gallus Gallus Bankia) dengan variasilama perendaman dan konsentrasi asam, Vol. 2,no. 3.

Puspawati, NM, Simpen, IN \& Miwada S, IN 2012, Isolasi gelatin dari kulit ayam broiler dan karakterisasi gugus fungsinya dengan spektrofotomtri FTIR, Uniersitas Udayana, Bukit Jimbaran Denpasar.

Poppe, J 1992,'Gelatindi dalam A. Imeson (ed). Thickening and gelling agent for food',Academic Press, New York.
Sankari, G., E. Kriahnamoorthy, S. Jayakumaran, S. Gunaeakaran, V.V. Priya, S. Subramanlam, S. Subramanlam, and S.K. Mohan 2010, Analysis of serum immunoglobulins using fourier transform.

Septimus, S 1961,'Anatomy of the domestic animal', Mc Graww Hill, New York.

Standar Nasional Indonesia (SNI) 1995, Mutu dan cara uji gelatin, Dewan Standarnisasi Nasional, Jakarta.

Suptijah, P, Suseno, H.S, dan Anwar, Cholil 2013, Analisis Kekuatan Gel (Gel Strength) Produk Permen Jelly dari Gelatin Kulit Ikan Cucut dengan Penambahan Karaginan dan Rumput Laut. JPHPI Vol. 16 No.2,Institut Pertanian Bogor, Bogor.

Widyaninggar, A, Triwahyudi, Triyana, K, Rohman, A 2008,'Differentiation between porcine and boine gelatin in commercial capsule shells based on amino acid profiles and principal component analysis',J Pharm Indonesia.

Wiratmaja, H 2006, Perbaikan Nilai Tambah Limbah Tulang ayam Tuna (thunnus sp) Menjadi Gelatin Serta Analisis FisikaKimia, Skripsi, IPB, Bogor. 